\title{
Analysis of the Relationship Between Private Investment and Public Investment in Mexico
}

\author{
Ana Laura Bojorquez Carrillo, Victor Manuel Villasuso Pino, Lilia Carolina Aviles Heredia \\ Faculty of Accounting and Administration, Autonomous University of Yucatan, Merida, Mexico \\ Email address: \\ anabc@correo.uady.mx (A. L. B. Carrillo),villapin@correo.uady.mx (V.M. V.Pino), haviles@correo.uady.mx (L. C. A. Heredia)
}

\section{To cite this article:}

Ana Laura Bojorquez Carrillo, Victor Manuel Villasuso Pino, Lilia Carolina Aviles Heredia. Analysis of the Relationship Between Private Investment and Public Investment in Mexico. International Journal of Economics, Finance and Management Sciences.

Vol. 6, No. 4, 2018, pp. 174-184. doi: 10.11648/j.ijefm.20180604.15

Received: July 16, 2018; Accepted: August 8, 2018; Published: September 15, 2018

\begin{abstract}
The aim of this study is to identify the relationships between domestic private investment and domestic public investment in Mexico. The hypotheses are as follows: H1 - Domestic public investment generates domestic private investment (period between 1993 and 2017); H2 - Domestic public investment generates domestic private investment (period between 1993 and 2008); H3 - Domestic public investment generates domestic private investment (period between 2009 and 2017). In order to analyze the relationship between the variables in this study we used the quarterly data series on public gross fixed capital formation (public GFCF) and private gross fixed capital formation (private GFCF) provided by the Mexican System of National Accounts, corresponding to the period between the first quarter of 1993 and the second quarter of 2017. In order to fulfill the aims of this study, the following stages were performed: identification of the time series models, using the methodology consisting of autoregressive integrated moving average models or ARIMA models; validation of the models identified; determination of the cross correlation function; and regression analysis of the transformed series. The main results of the study for the series from 1993 to 2017 show a statistically significant direct relationship between private investment and public investment. This confirms hypothesis 1: Domestic public investment generates domestic private investment (period between 1993 and 2017). The value of the Durbin-Watson statistic for this model is 2.103, meaning that the residuals are independent. The value of the constant in the model is not statistically significant. For the series from 1993 to 2008 there is a statistically significant direct relationship between private investment and public investment. This confirms hypothesis 2 : Domestic public investment generates domestic private investment, and the residuals are independent. With regard to the results for the series from 2009 to 2017, there is a statistically significant direct relationship between private investment and public investment. This confirms hypothesis 3: Domestic public investment generates domestic private investment (period between 2009 and 2017). The value of the Durbin-Watson statistic for this model is 1.74, meaning that the residuals are independent. The value of the constant in the model is statistically significant.
\end{abstract}

Keywords: Private Investment, Public Investment, Time-Series Models, Fiscal Policy and Crowding in

\section{Introduction}

Competitiveness between countries is an issue that took on greater emphasis in the neoliberal context, to the point that since 1979 the World Economic Forum has developed and published the Global Competitiveness Index (GCI) on an annual basis. The report on this index for 2017-2018 [1] states that it includes concepts related to productivity and long-term prosperity. It stresses the following elements as the second pillar of the GCI: infrastructure and connectivity, which include indicators such as road straightness, speed and quality; efficiency of underground transport; density, quality and efficiency of railroad services; connectivity, infrastructure quality and efficiency of air transport services; port infrastructure quality and efficiency; coverage and quality of the electrical supply; reliability, access and coverage of drinking water; and mobile network coverage. This second pillar forms part of what the GCI considers to be the basic requirements for managing the factors of the economy.

The importance of investment in infrastructure is also stressed in the [2], given that it considers that "adequate 
infrastructure and access to strategic inputs promote competition and permit greater flows of capital and knowledge to individuals and companies with the greatest potential to take advantage of them". Likewise, the Center for the Study of Public Finances [3] assures that "a shortage of basic infrastructure reduces economic competitiveness and the quality of human capital".

The above is confirmed by [4] in a series published by the International Monetary Fund, who state that the quality of physical infrastructure clearly affects a country's productivity, the competitiveness of its exports and its ability to attract foreign investment. They therefore encourage countries to increase public investment in infrastructure in a fiscally responsible manner. This consists of having healthy finances and optimal levels of debt and public savings, along with performing actions such as reallocating public spending, getting more out of investments through more careful planning, improved project evaluation and implementation procedures, considering likely future recurrent operation and maintenance costs, and promoting private sector investment.

Continuing with the emphasis that has been given internationally to public investment by international organizations, it is also worth noting that the [5] that "public investment is a potentially growth-enhancing form of public expenditure. In contrast, poor investment choices waste resources, erode public trust and may hamper growth opportunities".

Additionally, [6] in an Inter-American Development Bank (IDB) publication with data from 2003 to 2014, confirm that there is a positive relationship between public investment growth and gross domestic product (GDP) growth in some Latin American countries. Nevertheless, in their results it is notable that Mexico scores 2.5 points on the index of public investment management efficiency (on a scale where 0 is considered low and 4 high efficiency).

In general, therefore, it can be observed that international and national organizations favor public spending on infrastructure investment, in the hope that this will generate private investment, GDP growth and competitiveness.

Based on the above, the aim of this study is to determine the relationships between domestic private investment and domestic public investment. The hypotheses are as follows:

H1: Domestic public investment generates domestic private investment (period between 1993 and 2017).

H2: Domestic public investment generates domestic private investment (period between 1993 and 2008).

H3: Domestic public investment generates domestic private investment (period between 2009 and 2017).

\section{Methods and Techniques}

This study uses a non-experimental quantitative, crosssectional approach with an explanatory scope. In order to analyze the relationship between the variables in this study, consisting of domestic public investment and domestic private investment in Mexico, we used the quarterly data series on public gross fixed capital formation (public GFCF) and private gross fixed capital formation (private GFCF) provided by the Mexican System of National Accounts, corresponding to the period between the first quarter of 1993 and the second quarter of 2017 [7].

Gross fixed capital formation corresponds to the net flow of fixed assets (acquisitions less disposals) of public and private sector producers resident in a country in a certain period, including investment destined to cover the depreciation of capital and excluding land. Hereinafter, in this study we will call private fixed capital formation "private investment" and public fixed capital formation "public investment". The data for these two variables are presented in Figure 1.

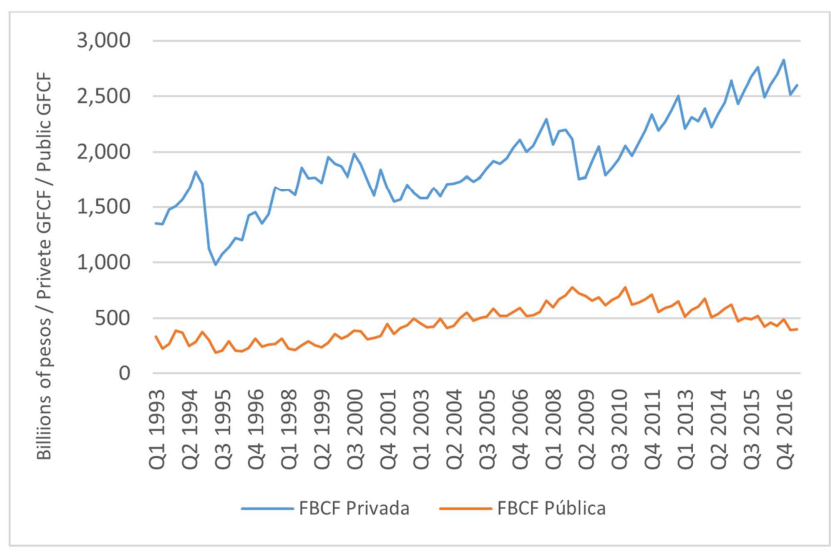

Figure 1. Mexico, quarterly private investment and public investment, 19932017.

As can be seen in the figure, between 1993 and 2008 both series present the same upward trend, while between 2009 and 2017 the trend is upwards for private investment and downwards for public investment. It is for this reason that it was decided to carry out an analysis of the time series in the two periods described, in addition to the general analysis of the period between 1993 and 2017.

An economic time series can be considered a succession of values over time, which is described as:

$$
y_{t}, y_{t-1}, y_{t-2}, y_{t-3}, \ldots, y_{3}, y_{2}, y_{1}
$$

such that the term $y_{t-p}$ represents the value of the series $p$ periods before the general reference period $t$.

As stated by several authors, such as [8], the series is called a non-stationary seasonal time series if it has a trend component and a seasonal component (periodic fluctuations over time). As such, in order to analyze it, the first objective is to convert it into a stationary deseasonalized series, which is performed by means of transformations on the original values of the series. The economic time series that we are dealing with are precisely non-stationary seasonal series.

In order to fulfill the aims of this study, the following stages were performed:

1. Identification of the time series models.

2. Validation of the models identified.

3. Determination of the cross correlation function.

4. Regression analysis of the transformed series. 
Stage 1: Identification of the time series models. BoxJenkins methodology

To conduct the analysis of the time series, which turned out to be non-stationary seasonal, the methodology proposed by Box and Jenkins was used, as also described by several authors, such as [9] and [10]. It consists of identifying the seasonal autoregressive integrated moving average models or ARIMA (p, d, q) (P, D, Q) models associated with the series under analysis, based on which it is possible to establish a possible relationship between these series. In this notation, the terms that appear in lower case correspond to the regular part and the terms in upper case to the seasonal part of the series under study.

According to this methodology, stabilization of the means or elimination of the trend of a non-stationary series is normally obtained by applying a differencing operator to the values of the series. The order of these differences for the regular part of the series is denoted by the letter $d$ and for the seasonal part by the letter D in the description of the model. Meanwhile, stabilization of the variances is normally obtained by applying a logarithmic transformation to the original data. The values $\mathrm{p}$ and $\mathrm{P}$ denote the presence or absence of an intervention variable and the letters $q$ and $Q$ the possible lags considered in the regular or seasonal part respectively. A more detailed description of these models, which were used in this study, is presented below.

a) Autoregressive models or AR models

An autoregressive model of order 1 AR (1) can be expressed as:

$$
y_{t}=\phi_{1} y_{t-1}+\phi_{0}+a_{t}
$$

In this model, a regression is performed of the time variable over itself with respect to the value it takes with a difference period. The parameters $\phi_{1}$ and $\phi_{0}$ are then estimated and it is hoped that the random error $a_{t}$ does not present autocorrelation.

If the difference to be considered is of order $\mathrm{p}$, the model becomes;

$$
y_{t}=\phi_{1} y_{t-1}+\phi_{2} y_{t-2}+\ldots+\phi_{p} y_{t-p}+\phi_{0}+a_{t}
$$

which entails estimating $p$ parameters plus $\phi_{0}$, and in this case it consists of an autoregressive model of order $p$ or AR (p).

b) Moving average models or MA models

An alternative explanation for the time variable $y_{t}$ is through the errors on estimating it in previous periods, with respect to a mean value, such that the model of moving means (or averages) of order 1 (that is, considering a previous period) is expressed as:

$$
y_{t}=\mu+\theta_{1} a_{t-1}+a_{t}
$$

where $\mu$ is the constant value around which the time variable moves and $\theta_{1}$ is the parameter to be estimated.

If $q$ previous periods are considered, the expression of the model is:

$$
y_{t}=\mu+\theta_{1} a_{t-1}+\theta_{2} a_{t-2}+\ldots+\theta_{q} a_{t-q}+a_{t}
$$

which entails estimating $q$ parameters, and in this case we are referring to a model of moving means or averages of order $q$ or MA (q).

c) ARMA models

ARMA models join the AR and MA models, such that an ARMA model of order $p$ for the autoregressive component and of order $q$ for the moving averages component is expressed as:

$$
y_{t}=\mu+\phi_{1} y_{t-1}+\ldots+\phi_{p} y_{t-p}+\ldots+\theta_{1} a_{t-1}+\ldots+\theta_{q} a_{t-q}+a_{t}
$$

that is, the model is the union of the model AR (p) with the model MA (q) and is synthetically expressed as ARMA (p, q).

d) Autoregressive integrated moving average (ARIMA) models

To adequately estimate the ARIMA model it is necessary for the series to be stationary in mean and variance. In the case of economic series that are usually not stationary, this is generally achieved by applying logarithms (to stabilize the variance) and differences between the values of the series (to

$$
\Delta^{d} y_{t}=\mu+\phi_{1} \Delta^{d} y_{t-1}+\ldots+\phi_{p} \Delta^{d} y_{t-p}+\ldots+\theta_{1} a_{t-1}+\ldots+\theta_{q} a_{t-q}
$$

e) Seasonal ARIMA or ARIMA (p, d, q) (P, D, Q) models

In seasonal ARIMA models, not only are the $\mathrm{p}, \mathrm{d}, \mathrm{q}$ parameters of the regular part of the series estimated, but also the P, D, Q parameters of the seasonal component, where for this component $\mathrm{P}$ is the autoregressive order, $\mathrm{D}$ is the difference that eliminates the possible trend of the component, and $\mathrm{Q}$ is the order of its moving average component.

If seasonality is present in the series, seasonal ARIMA stabilize the mean). The order of these differences is the order of integration of the series.

An autoregressive integrated moving average model ARIMA (p, d, q) is an ARMA (p, q) model applied to an integrated series of order d, denoted as I (d), that is, which it was necessary to difference $\mathrm{d}$ times to eliminate the trend.

According to the above, the expression for an ARIMA ( $p$, d, q) model obtained by applying d differences to the ARMA model is:

models or SARIMA models must be considered, denoted ARIMA (p, d, q) (P, D, Q), where the lowercase letters correspond to the order of the components of the series in its regular part (non-seasonal) and the uppercase letters correspond to the components of the series in its seasonal part.

In our case, the ARIMA models identified turned out to be seasonal, that is, of the form ARIMA (p, d, q) (P, D, Q). This identification was carried out using the statistical package 
IBM SPSS Statistics, version 22.

In general, as stated by authors such as [11], the identification of these models is performed based on the analysis of the autocorrelation function (ACF) and partial autocorrelation function (PACF).

The autocorrelation function (ACF) measures the correlation between two variables separated by $\mathrm{k}$ periods, whose values can be obtained by means of the expression:

$$
\rho_{j k}=\frac{\operatorname{cov}\left(y_{j}-y_{j-k}\right)}{\sqrt{V\left(y_{j}\right)} \sqrt{V\left(y_{j-k}\right)}}
$$

Meanwhile, the partial autocorrelation function (PACF) measures the correlation between two variables separated by $\mathrm{k}$ periods when the dependence created by the intermediate lags between them is excluded.

Stage 2. Validation of the models identified

A range of statistical tests are used to determine the suitability and goodness of fit of the model considered for the purposes of this study. These measures include the $\mathrm{R}^{2}$ and stationary $\mathrm{R}^{2}$ coefficients, as well as the mean absolute error (MAE), the mean absolute percentage error (MAPE), the root mean square error (RMSE) and the Ljung-Box Q test. In the case of the latter, the null hypothesis confirms the nonautocorrelation of the residuals associated with the model, which represents a good fit. This test is described below.

Ljung-Box-Q test

The non-autocorrelation of the residuals or random errors is a desirable assumption associated with time series and can be verified by means of the Ljung-Box-Q test. The null hypothesis $\left(\mathrm{H}_{0}\right)$ of this test is that the values are independent, while the alternative hypothesis $\left(\mathrm{H}_{\mathrm{a}}\right)$ is that they are not. The test statistic is given by the expression:

$$
Q=n(n+2) \sum_{k=1}^{m} \frac{\widehat{\rho}_{k}}{n-k}
$$

where $n$ is the sample size or number of observations, $\hat{\rho}_{k}$ is the value of the estimator of the sample autocorrelation at lag $k$, and $m$ is the number of lags considered.

The value of the autocorrelation estimator can be obtained by means of the expression:

$$
\hat{\rho}_{k}=\frac{\sum_{j=k+1}^{n}\left(y_{j}-\bar{y}\right)\left(y_{j-k}-\bar{y}\right)}{\sum_{j=1}^{n}\left(y_{j}-\bar{y}\right)^{2}}
$$

The Q statistic of the Ljung-Box test follows a chi-squared distribution with $m$ degrees of freedom, such that $\mathrm{H}_{0}$ is rejected if

$$
Q>\chi_{1-\alpha, m}^{2}
$$

Verification of the stationarity of the models

Two uncorrelated non-stationary series can present an apparent significant relationship under regression analysis, such that, in order to rule out a possible spurious relationship in the analysis of the relationship between two time series, their corresponding stationary transformed series must be analyzed.

The stationarity of the models obtained was verified by means of augmented Dicky-Fuller (ADF) unit root tests and the Phillips-Perron (PP) test, for which the null hypothesis is the presence of a unit root, that is, the series is not stationary; and by means of the Kwiatkowski-Phillips-Schmidt-Shin (KPSS) test, for which the null hypothesis is, in contrast, that the series is stationary. These tests mentioned by authors such as [12], [13] and [14] are described below.

a) Dicky-Fuller test

The test is based on the AR (1) model, which can be written as:

$$
y_{t}=\rho y_{t-1}+a_{t}
$$

where the unit root is present if $\rho=1$, in which case the model would not be stationary.

By applying the differencing operator to the previous expression it is transformed into:

$$
\Delta y_{t}=(\rho-1) y_{t-1}+a_{t}
$$

This last expression can be seen as a regression model with $\delta=\rho-1$

$$
\Delta y_{t}=\delta y_{t-1}+a_{t}
$$

such that the statistical significance of $\delta$ can be verified by testing the hypothesis

$\mathrm{H}_{0}: \delta=0$ (the series has a unit root, that is, it is not stationary) against $\mathrm{H}_{\mathrm{a}}: \delta<0$ (the series does not have a unit root).

The augmented Dickey-Fuller (ADF) test is based on the above result, but takes a more advanced model than AR (1) as a reference.

b) Phillips-Perron (PP) test

The Phillips-Perron (PP) test verifies the same hypothesis as above by performing a non-parametric correction to the test statistic of the statistical significance of the coefficient $\delta$, and is therefore considered a more robust statistical test against the possible presence of autocorrelation in the series under analysis.

c) KPSS test

The Kwiatkowski-Phillips-Schmidt-Shin (KPSS) tests permits the verification of the presence $\left(\mathrm{H}_{0}\right)$ or absence $\left(\mathrm{H}_{\mathrm{a}}\right)$ of stationarity in the trend, which corresponds to the fact that for this test the null hypothesis $\left(\mathrm{H}_{0}\right)$ is that the series is stationary and the alternative hypothesis $\left(\mathrm{H}_{\mathrm{a}}\right)$ is that the series is not stationary; that is, the formulation is the reverse of the two tests described previously.

Once the model has been identified, the values of the stationary transformed series are used to identify the relationship between the series under study, by means of the cross correlation coefficient and regression analysis between the values of these series.

Stage 3. Determination of the cross correlation function Cross correlation function

Given a time series of $\mathrm{n}$ periods of a stationary bivariate time series (that is, two stationary time series of $\mathrm{n}$ periods), the correlation between the series under study was determined by means of the cross correlation function, the 
estimation of which according to a number of authors, such as [15] and [16], can be obtained from the expression:

$$
\gamma_{x y}(k)=\frac{\frac{1}{n} \sum_{j=1}^{n-k}\left(x_{j}-\bar{x}\right)\left(y_{j+k}-\bar{y}\right)}{\sqrt{V(x)} \sqrt{V(y)}}
$$

According to Bartlett, the null hypothesis of no cross correlation can be tested against the presence of this correlation between the series, considering as the standard error:

$$
\sqrt{(n-k)^{-1}}
$$

Stage 4. Regression of the transformed time series

As has been mentioned, the order of integration of a variable corresponds to the number of differences required to make it stationary, such that, as stated by several authors such as [17], to establish the relationship between the stationary transformed series by regression analysis, these must be cointegrated I (d), that is, the order of the differences $d$ to make them stationary must be the same. The regression is performed between the transformed series to avoid obtaining a spurious correlation as a result of obtaining the correlation coefficient between the original non-stationary series.

Accordingly, the regression model between the transformed series can be expressed as:

$$
y_{t}=\beta_{o}+\beta_{1} x_{t}+a_{t}
$$

In our case, the two series analyzed corresponding to private investment and public investment turned out to have the same order of integration, such that the regression analysis was applied between the stationary transformed series associated with the two series.

\section{Fiscal Policy and Crowding in}

The purpose of a public policy is to direct the actions of a country to solve specific problems and in specific contexts, the causes of which have previously been analyzed and a consensus on them reached with the citizenry. As such, the ultimate purpose of a public policy is to improve people's lives.

According to [18] "a public policy is composed of a set of decisions and actions aimed at resolving a public problem. The solution to this problem depends not only on the suitability of the design of the public policy, but also on its effective implementation".

Fiscal policy, according to the [19] is a branch of economic policy and "is understood to be the set of instruments and the measures the State takes with the aim of collecting the necessary revenue to perform the functions that help it to fulfill its economic policy objectives, through public spending". It is important to stress that, according to the CIEP, fiscal policy in the field of public finances seeks a balance between what is collected through taxes - and other items - and government spending. In this regard, the CIEP states that the State budget and its components (public spending and taxes) are used as control variables to ensure and maintain economic stability, cushioning the variations of economic cycles and contributing to maintaining a growing economy. Accordingly, "one of the most important instruments the Federal Government has at its disposal to perform its functions in terms of Public Finances is tax policy". In Mexico, tax policy is reflected in the Federal Revenue Law (Ley de Ingresos de la Federación; LIF) on the side of revenue, and on the side of spending a document is issued called the Federal Expenditures Budget (Presupuesto de Egresos de la Federación; PEF), regulated in the Law on Fiscal Budgets and Responsibility (Ley Federal de Presupuestos y Responsabilidad Hacendaria).

The principle of budgetary balance is one of the main principles of the budget. This principle is regulated in Article 17 of the Political Constitution of the United Mexican States [20] "The total net expenditure proposed by the Federal Executive in the draft Expenditures Budget, that which is approved by the House of Representatives and that which is exercised in the fiscal year by the expense executors, must contribute to budgetary balance".

Fonrouge, as cited by [21] states that traditionally there was an idea of a purely financial or accounting balance. However, in modern theories, this has been replaced by an economic balance, thereby manifesting an evolution of the static towards the dynamic.

In the budgetary balance, therefore, there are two main elements: revenue and expenditure. With regard to public spending, this can be defined as "the set of expenditures, generally monetary, performed both by the bodies of the State and other public entities, which affects the state finances, and which has the purpose of satisfying the objectives and aims that the State proposes for a certain fiscal year" [22].

Public spending can be classified as current or operational expenditure; and capital or investment expenditure, and depending on its regularity can be classified as ordinary and extraordinary. The item of current or operational expenditure refers to expenditure that is focused on paying for ongoing requirements, such as salaries of public servants, among others. On the other hand, capital or investment expenditure is required for large works planned with a collective benefit and for more than one fiscal year, such as the construction of airports or roads. Ordinary spending is projected to cover a certain fiscal year with previously approved projects and plans. In contrast, extraordinary expenditure is carried out urgently to meet the unexpected needs of society [22].

Public spending is productive if it increases the profitability of investment in general, by promoting private investment and economic growth. On the other hand, unproductive public spending acts in the opposite manner [23]. The golden rule, therefore, as mentioned by [24], is to identify and divide the public budget into two: current expenditure and investment expenditure. The former must be undertaken with a savings-based approach, but increasing the latter to generate a procyclical fiscal policy is justified, even when taking on limited levels of debt.

Based on the above, it is important to note that although it 
is necessary to seek a financial balance between revenue and expenditure, it is also necessary to seek and oversee the economic balance between current expenditure and investment expenditure. The following section includes an analysis of the effects generated by the productive and efficient use of investment expenditure.

Crowding in

The "crowding in" effect occurs when increases in public investment produce incentives for private investment, which should occur when both types of investment are complementary. One of the tendencies that support this assumption is the Keynesian one [25]. Under the Keynesian model, public investment has an effect on private capital formation and therefore on economic growth, not just due to increased aggregate demand for goods and services produced by the private sector, but also due to the influence of future profit and sales expectations of private investors [26].

The opposite effect ("crowding out") occurs when there are degrees of substitution between the two; that is, under this effect significant impacts on growth may not occur [27]. [25] states that crowding out is a displacement effect, which refers to a situation in which public sector spending displaces its counterpart in the private sector. Carlos and Spencer, as cited by [25], state that this effect refers to the effects of expansive fiscal policies, "if an increase in government demand, whether financed by taxes or public bond issues, fails to stimulate economic activity as a whole, then the private sector is said to have been displaced by government action".

According to [28], the majority of empirical studies (using vector autoregressions; VARs) conclusively show that private consumption reacts positively to a public spending expansion. Nevertheless, some authors have found that the investment of private capital acts in the opposite manner (see Table 1).

Table 1. Effects of public spending expansion in the United States: Empirical results.

\begin{tabular}{lll}
\hline Investigation & Consumption response & Private investment response \\
\hline Alesina et al. (2002) & N. A. & Negative \\
Blanchard and Perotti (2002) & Positive & Negative \\
Ben Zeev and Pappa (2017) & Positive & Positive \\
Burnside et al. (2004) & Not significant & Positive \\
Caldara and Kamps (2008) & Positive & N. A. \\
Edelberg et al. (1999) & Negative & Positive \\
Fatás and Mihov (2001) & Positive & Positive \\
Fisher and Peters (2010) & Positive & N. A. \\
Galí et al. (2007) & Positive & Not significant \\
Monacelli and Perotti (2008) & Positive & Negative \\
Mountford and Uhlig (2009) & Positive & Negative \\
Ramey (2011) & Negative & Negative \\
Ravn et al. (2012) & Positive & N. A. \\
\hline
\end{tabular}

Source: Lewis y Winkler (2017, p. 944).

The results of their study indicate that, in effect, public spending expansions generate greater private consumption and increase firm market entry.

In the case of Ibero-America, [27] identified that there are also studies such as González-Páramo and López (2003) in Spain, Cobacho, Bosch and Rodríguez (2004) in Mexico, and Párraga (2014) in the case of Bolivia ${ }^{1}$, among others, which suggest that public investment positively impacts growth, although not in $100 \%$ of cases, and not always significantly.

In the specific case of Mexico, [25] identifies that no consensus exists between the type of relationship generated between public investment and private investment (see Table 2).

Table 2. Relationship between public investment (independent variable) and private investment (dependent variable) in the case of the Mexican economy.

\begin{tabular}{ll}
\hline Study & Crowding in or crowding out \\
\hline Shah (1988) & Crowding in \\
Musalem (1989) & Crowding in (in the short and long term) \\
Ramírez (1994) & Crowding in (in the long term) \\
Moreno-Brid (1999) & Crowding in (with an panel analysis at \\
& the level of industries) \\
\hline
\end{tabular}

1 Authors cited by Armendáriz, Contreras, Orozco and Parra (2016).

\begin{tabular}{ll}
\hline Study & Crowding in or crowding out \\
\hline Aschauer and Lächler (1998) & Crowding out \\
Ramírez and Nader (1997) & Crowding out \\
Herrera (2003) & Crowding out \\
Castillo and Herrera (2005) & $\begin{array}{l}\text { Crowding out in the long term, but } \\
\text { crowding in the short term. }\end{array}$ \\
\hline
\end{tabular}

Source: Prepared by the authors based on Fonseca (2009).

The problem of this discrepancy in the results is identified in the hypothesis studied [27], when they mention that "the quality of the National Systems of Public Investment may be making the difference in the magnitude of the impact of public investment on economic growth". In their study, the authors constructed an index of the efficiency of the management of public spending that allows benchmarking as well as the measurement of relative strengths and weaknesses for each country.

The index of the efficiency of the management of public spending for Mexico in the study of [27] was 2.5 (on a scale of 0 to 4 , where 0 is considered low efficiency and 4 high efficiency). The worst-assessed dimension in Mexico was "ex post assessment", and the best-assessed was "project implementation".

To contribute to the efficacy of public investment, the [6] 
outlines the following principles to strengthen it at all levels of government:

A. Coordinate public investment across all levels of government

1 Invest using an integrated strategy tailored to different places.

2 Adopt effective instruments for coordinating across national and sub-national levels of government.

3 Coordinate horizontally among sub-national governments to invest at the relevant scale.

B. Strengthen capacities for public investment and promote learning at all levels of government

1 Assess upfront the long-term impacts and risks of public investment.

2 Engage with stakeholders throughout the investment cycle.

3 Mobilize private actors and financing institutions to diversify sources of funding and strengthen capacities.

4 Reinforce the expertise of public officials and institutions involved in public investment.

5 Focus on results and promote learning from experience.

C. Ensure proper framework conditions for public investment at all levels of government

1 Develop a fiscal framework adapted to the investment objectives.
2 Require sound and transparent financial management at all levels of government.

3 Promote transparency and strategic use of public procurement at all levels of government.

4 Strive for quality and consistency in regulatory systems across levels of government.

Reference [28] assert the neither the real economic business cycle model nor the standard neo-Keynesian model is capable of generating crowding in of private consumption. The reason is the strength of the effect that predicts that the expectation of increased taxes on the sum total of income causes people to consume less and work more.

Based on this theoretical framework, the results of this study were analyzed to identify the relationships between domestic public investment and domestic private investment in the period from 1993 to 2017.

\section{Results}

a) Results for the series from 1993 to 2017

Through the use of the statistical package IBM SPSS Statistics version 22, an ARIMA $(0,1,0)(0,1,1)$ model was identified for both private investment and public investment; that is, a logarithmic transformation is considered with a first order difference, in order to make both series stationary. The graphs corresponding to the transformed series are presented below.

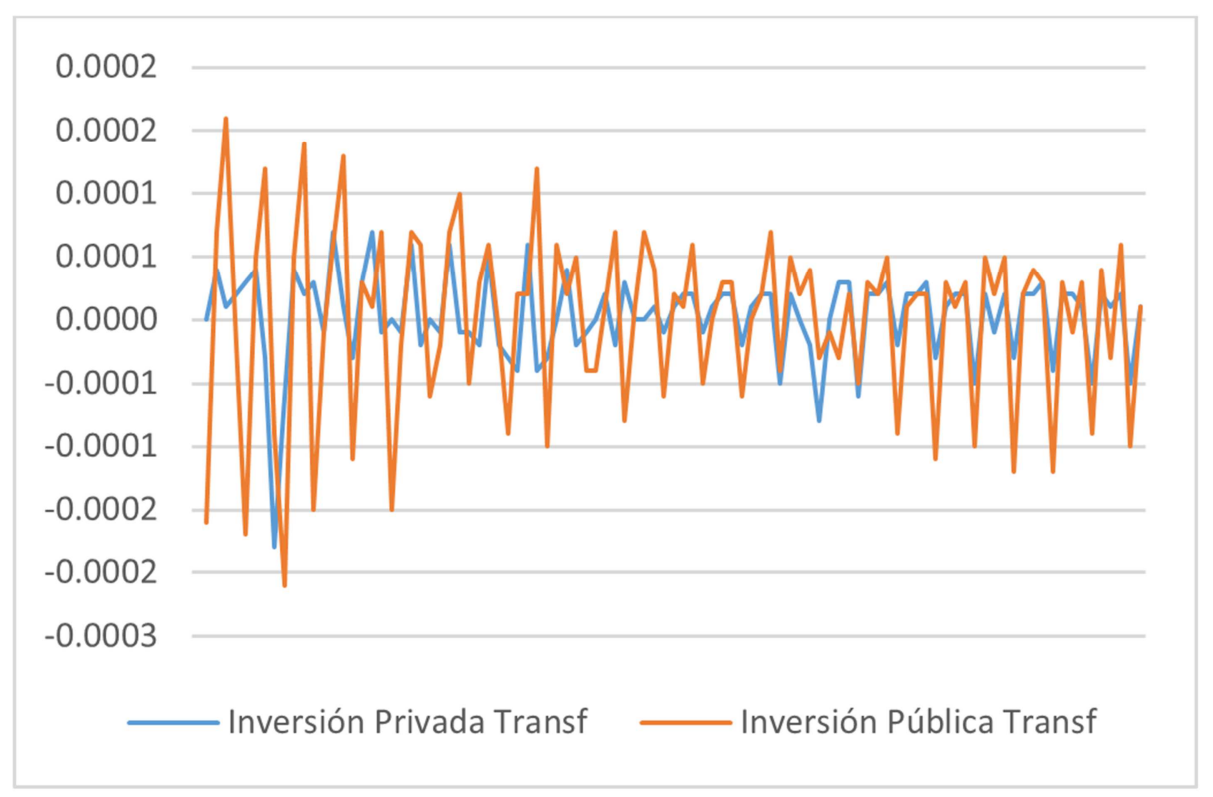

Figure 2. Transformed series, quarterly private and public investment, 1993-2017.

For the private and public investment series, the parameters of the ARIMA model including the regular difference, the seasonal difference and the seasonal lag are presented in the following table.

Table 3. Parameters of the ARIMA model for private investment and public investment, 1993-2017.

\begin{tabular}{lllll}
\hline Series & Parameter & Estimate & Standard error & t \\
\hline Private investment & Constant & 483.965 & $3,558.302$ & 0.136 \\
& Regular difference & 1 & & 0.892 \\
& Seasonal difference & 1 & & \\
& Seasonal lag & 0.709 & 0.082 & 8.605 \\
\hline
\end{tabular}




\begin{tabular}{llllll}
\hline Series & Parameter & Estimate & Standard error & t & p-value \\
\hline Public investment & Constant & -433.989 & $1,571.928$ & -0.276 & 0.783 \\
& Regular difference & 1 & & & \\
& Seasonal difference & 1 & & & \\
& Seasonal lag & 0.579 & 0.093 & 6.225 & 0.000 \\
\hline
\end{tabular}

Source: Prepared by the authors based on the results obtained by means of the package IBM SPSS Statistics, version 22.

Regarding the measures of goodness of fit of the models for the private and public investment series, considering the original units of measure of the data (millions of pesos), the value of $\mathrm{R}^{2}$, stationary $\mathrm{R}^{2}$, as well as the value of the mean absolute error (MAE), mean absolute percentage error (MAPE), the root mean square error (RMSE) and the Ljung-Box-Q test with regard to the null hypothesis or non-autocorrelation of the residuals were satisfactory. The results obtained are presented in the following table.

Table 4. Goodness of fit measures of the models of private investment and public investment, 1993-2017.

\begin{tabular}{|c|c|c|c|c|c|c|}
\hline Series & $\mathbf{R}^{2}$ & Stationary $\mathbf{R}^{2}$ & MAE & MAPE & RMSE & Ljung-Box-Q p-value \\
\hline Private investment & 0.921 & 0.268 & $76,021.0$ & $4.6 \%$ & $113,840.3$ & 0.221 \\
\hline Public investment & 0.953 & 0.261 & $25,927.8$ & $6.5 \%$ & $34,016.7$ & 0.635 \\
\hline
\end{tabular}

Source: Prepared by the authors based on the results obtained by means of the package IBM SPSS Statistics, version 22.

The stationarity of the transformed series was verified by means of the Dicky-Fuller, Phillips-Perron and KPSS tests. In the case of the first two, the null hypothesis $\left(\mathrm{H}_{0}\right)$ is that the series does not have a unit root (that is, the series is not stationary), while for the KPSS test the null hypothesis $\left(\mathrm{H}_{0}\right)$ is that the series is stationary. The results obtained by means of the XLSTAT Premium 2017 package are presented in the following table.

Table 5. Verification of the stationarity of the transformed series of private and public investment, 1993-2017.

\begin{tabular}{lll}
\hline Serie & Proof & Valor-p \\
\hline Private investment & Dickey Fuller (ADF) & 0.000 \\
& Phillips Perron (PP) & 0.000 \\
& KPSS & 0.995 \\
Public investment & & 0.019 \\
& Dickey Fuller (ADF) & 0.000 \\
& Phillips Perron (PP) & 0.585 \\
\hline
\end{tabular}

Source: Own elaboration based on the results obtained with the package XLSTAT Premium, 2017.

Considering a significance level of 0.05 , the above results confirm the stationarity of the transformed series.

The graph corresponding to the adjusted models is presented below.

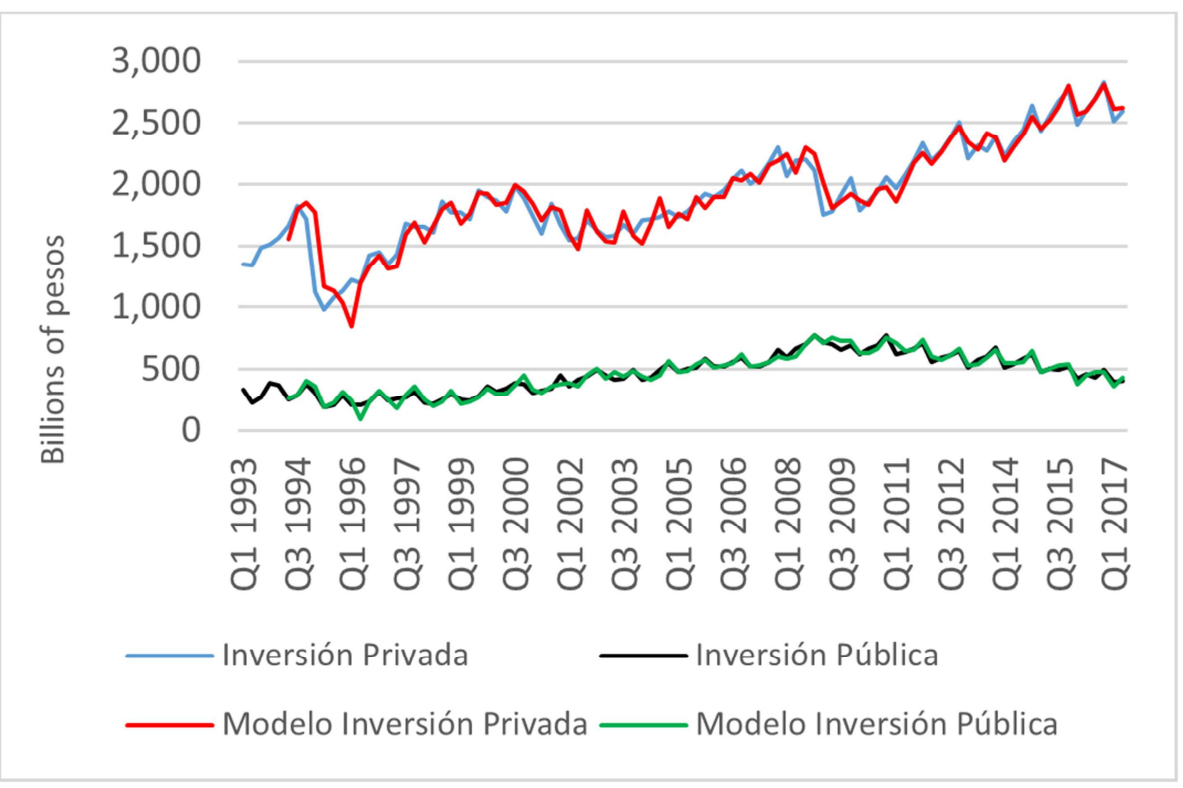

Figure 3. Adjusted series and models, quarterly private investment and public investment, 1993-2017. 
According to the above results, the two transformed series are cointegrated, with an order of cointegration of 1, given that because they were not originally stationary, by applying a difference I (1), they were both converted to stationary series.

Next the cross correlation coefficient between the two transformed time series was obtained $(\mathrm{r}=0.411$, $\mathrm{p}$-value $=$ $0.000)$, which turns out to be the same as the one associated with the regression model for the relationship between private investment (Invpriv, as the dependent variable) and public investment (Invpub, as the independent variable). The associated regression model turns out to be:

$\operatorname{Invpriv}(\operatorname{transf})=0.204 * \operatorname{Invpub}($ trans $f)+0.003(18)$
According to the results of the regression, in the period under consideration there is a statistically significant direct relationship ( $\mathrm{p}$-value $=0.000$ for the slope) between private investment and public investment. This confirms hypothesis 1: Domestic public investment generates domestic private investment (period between 1993 and 2017). The value of the Durbin-Watson statistic for this model is 2.103 , meaning that the residuals are independent. The value of the constant in the model is not statistically significant ( $p$-value $=0.404$ ).

b) Results for the series from 1993 to 2008

For this period, the parameters of the models obtained for the ARIMA $(0,1,0)(0,1,1)$ models for both private investment and public investment are presented in the following table.

Table 6. Parameters of the models ARIMA for Private Investment and Public Investment (1993-2008).

\begin{tabular}{|c|c|c|c|c|c|}
\hline Serie & Parameter & Estimate & Error estand & $\mathbf{t}$ & Valor p \\
\hline \multirow[t]{3}{*}{ Private Investment } & Constant & 417.863 & $3,864.259$ & 0.108 & 0.914 \\
\hline & Regular difference & 1 & & & \\
\hline & Seasonal difference & 1 & & & \\
\hline \multirow[t]{3}{*}{ Public Investment } & Constant & $1,746.612$ & $2,081.382$ & 0.839 & 0.405 \\
\hline & Regular difference & 1 & & & \\
\hline & Seasonal difference & 1 & & & \\
\hline
\end{tabular}

Source: Own elaboration based on the results obtained through the package IBM SPSS Statistics, versión 22.

As can be seen in the following table, the goodness of fit measures of the models of the series under study turned out to be satisfactory.

Table 7. Measures of goodness of fit of the models of Private Investment and Public Investment, 1993-2008.

\begin{tabular}{|c|c|c|c|c|c|c|}
\hline Serie & $\mathbf{R 2}$ & R2 stationary & MAE & MAPE & RMSE & Valor p Ljung-Box-Q \\
\hline Private Investment & 0.793 & 0.261 & 90,331 & $5.8 \%$ & $132,551.0$ & 0.722 \\
\hline Public Investment & 0.943 & 0.264 & 25,455 & $7.5 \%$ & $34,180.0$ & 0.246 \\
\hline
\end{tabular}

Source: Own elaboration based on the results obtained through the package IBM SPSS Statistics, version 22.

The stationarity of the transformed series was verified by means of the Dicky-Fuller, Phillips-Perron and KPSS tests. The results of these tests are presented below.

Table 8. Verification of the stationarity of the series. Transformed Private and Public Investment, 1993-2008.

\begin{tabular}{lll}
\hline Serie & Proof & Valor-p \\
\hline Private Investment & Dickey Fuller (ADF) & 0.063 \\
& Phillips Perron (PP) & 0.000 \\
& KPSS & 0.988 \\
& & \\
Public Investment & Dickey Fuller (ADF) & 0.055 \\
& Phillips Perron (PP) & 0.000 \\
& KPSS & 0.736 \\
\hline
\end{tabular}

Source: Own elaboration based on the results obtained with the package XLSTAT Premium, 2017.

The above results confirm the stationarity of the transformed series.

Next the cross correlation coefficient between the two transformed time series was obtained $(\mathrm{r}=0.299$, $\mathrm{p}$-value $=$ 0.009 ), which turns out to be the same as the one associated with the regression model for the relationship between private investment (Invpriv, as the dependent variable) and public investment (Invpub, as the independent variable), based on the transformed series. In this case, the associated regression model is:

$$
\operatorname{Invpriv}(\operatorname{trans} f)=0.144 * \operatorname{Invpub}(\operatorname{trans} f)+0.002(19)
$$

According to the results obtained, in the period under consideration there is a statistically significant direct relationship ( $\mathrm{p}$-value $=0.017$ for the slope) between private investment and public investment. This confirms hypothesis 2: Domestic public investment generates domestic private investment (period between 1993 and 2008). The value of the Durbin-Watson statistic for this model is 2.04 , meaning that the residuals are independent. The value of the constant in the model is not statistically significant ( $\mathrm{p}$-value $=0.625$ ).

c) Results for the series from 2009 to 2017

The parameters of the models obtained for the ARIMA $(0$, $1,0)(0,1,1)$ models for both private investment and public investment are presented in the following table. 
Table 9. Parameters of the models ARIMA for Private Investment and Public Investment, 2009-2017.

\begin{tabular}{|c|c|c|c|c|c|}
\hline Serie & Parameter & Estimate & Error estand & t & Valor p \\
\hline \multirow[t]{4}{*}{ Private Investment } & Constant & $-2,350.431$ & $4,615.019$ & -0.509 & 0.615 \\
\hline & Regular difference & 1 & & & \\
\hline & Seasonal difference & 1 & & & \\
\hline & Seasonal delay & 0.782 & 0.289 & 2.706 & 0.012 \\
\hline \multirow[t]{4}{*}{ Public Investment } & Constant & 719.574 & $2,155.488$ & 0.334 & 0.741 \\
\hline & Regular difference & 1 & & & \\
\hline & Seasonal difference & 1 & & & \\
\hline & Seasonal delay & 1 & 824.142 & 0.001 & 0.999 \\
\hline
\end{tabular}

Source: Own elaboration based on the results obtained through the package IBM SPSS Statistics, version 22.

Regarding the goodness of fit measures of these models, these turned out to be satisfactory, as can be observed in the following table.

Table 10. Measures of goodness of fit of the models of Private Investment and Public Investment, 2009-2017.

\begin{tabular}{lllllll}
\hline Serie & R2 & R2 stationary & MAE & MAPE & RMSE & Valor p Ljung-Box-Q \\
\hline Private Investment & 0.937 & 0.270 & 45,924 & $2 \%$ & $64,190.0$ & 0.565 \\
Public Investment & 0.873 & 0.016 & 28,067 & $5 \%$ & 36,079 & 0.547 \\
\hline
\end{tabular}

Source: Own elaboration based on the results obtained through the package IBM SPSS Statistics, versión 22.

The results of the stationarity tests of the series are presented in the following table.

Table 11. Verification of the stationarity of the series Transformed Private and Public Investment, 2009-2017.

\begin{tabular}{lll}
\hline Serie & Proof & Valor-p \\
\hline Private Investment & Dickey Fuller (ADF) & 0.433 \\
& Phillips Perron (PP) & 0.000 \\
& KPSS & 0.615 \\
& & \\
Public Investment & Dickey Fuller (ADF) & 0.104 \\
& Phillips Perron (PP) & 0.000 \\
& KPSS & 0.985 \\
\hline
\end{tabular}

Source: Own elaboration based on the results obtained with the package XLSTAT Premium, 2017.

While the ADF test was not satisfactory for this period, the results of the other two tests allow us to consider that the transformed series are stationary.

Next the cross correlation coefficient between the two transformed time series was obtained $(\mathrm{r}=0.845$, $\mathrm{p}$-value $=$ $0.000)$, which turns out to be the same as the one associated with the simple linear regression model for the relationship between private investment (as the dependent variable) and public investment (as the independent variable), based on the transformed series. In this case, the associated regression model is:

$$
F B C F p r i v(\operatorname{trans} f)=0.418 * F B C F p u b(\operatorname{trans} f)+0.008
$$

According to the results obtained, in the period under consideration there is a statistically significant direct relationship ( $\mathrm{p}$-value $=0.000$ for the slope) between private investment and public investment. This confirms hypothesis 3: Domestic public investment generates domestic private investment (period between 2009 and 2017). The value of the Durbin-Watson statistic for this model is 1.74 , meaning that the residuals are independent. The value of the constant in the model is statistically significant ( $p$-value $=0.004$ )

\section{Conclusions}

As can be observed in the first two figures, between 1993 and 2008 both series presented an upward trend. Nevertheless, between 2009 and 2017, the trend was upward for private investment and downward for public investment.
This was the reason for carrying out specific analyses for each of the periods: $1993-2008$ and 2009-2017, in addition to the general analysis of the full period of 1993-2017.

The results show that in the three periods under consideration there is an important, direct and statistically significant relationship between private investment and public investment, which is to say that with greater public investment there is greater private investment.

It is worth stressing that in the 2009-2017 period, where a discrepancy was observed between the trends between private investment and public investment (the trend of the data on private investment is upward and the trend for public investment is downward), this inverse relationship was not corroborated. In other words, when looking at the situation individually by year, it is observed that the aforementioned relationship is maintained (with greater public investment 
there is greater private investment).

As occurs in all studies, the limitations of this study present us with new opportunities to further this research. It is therefore recommended to explore and identify the causes of the inverse trend between the two variables for the final period of 2009-2017, with possible causes including the effect of the consequences of the 2008 global financial crisis, the fiscal policies applied in Mexico as a strategy to counteract this crisis, and the possible private investment opportunities generated after the crisis.

\section{References}

[1] World Economic Forum (2016). The Global Competitiveness Report 2016-2017. Ginebra: World Economic Forum.

[2] Plan Nacional de Desarrollo 2013-2018, p. 22.

[3] Centro de Estudios de las Finanzas Públicas (2017). Glosario de Términos más Usuales de Finanzas Públicas. México: Centro de Estudios de las Finanzas Públicas (CEFO), Órgano de apoyo técnico de la Cámara de Diputados.

[4] Akitoby, B., Hemming, R. y Schwartz, G. (2007). Inversión pública y asociaciones público-privadas. Washington, D. C.: Fondo Monetario Internacional.

[5] OCDE (2014). Inversión pública efectiva en todos los niveles de gobierno. Principios de acción. México: OCDE, p. 2.

[6] Armendáriz, E. y Contreras, E. (2016). El gasto de inversión pública en América Latina: cuánto y cuán eficiente. $6^{\circ}$ seminario de la Red de Sistemas Nacionales de Inversión Pública de América Latina y el Caribe. Banco Interamericano de Desarrollo.

[7] INEGI (2017). Sistema de Cuentas Nacionales de México. Consultado el 5 de octubre de 2017, Recuperado de:http://www.banxico.org.mx/SieInternet/consultarDirectorio InternetAction.do?accion $=$ consultarCuadro\&idCuadro $=$ CR15 1.

[8] Makridakis, S. y Wheelwrigth, S. C. (2009). Métodos de Pronósticos, $1^{\mathrm{a}}$. ed., Limusa, México.

[9] Bowerman, O’Connell y Koehler (2007). Pronósticos, Series de Tiempo y Regresión, 4a ed. México: Cengage Learning.

[10] Hanke y Wichern (2010). Pronósticos en los Negocios, 9a ed., México: Pearson.

[11] Peña, D. (2005). Análisis de Series Temporales, Madrid: Alianza Editorial.

[12] Chumacero R. (2000). Se busca una raíz unitaria: evidencia para Chile. Revista Estudios de Economía, 27 (1). Chile: Universidad de Chile, Departamento de Economía.

[13] Presno N. y López A. (2001). Tratamiento Estadístico de Series con cambios estructurales: Un caso de estudio, Revista Asturiana de Economía, 22, Oviedo: Universidad de Oviedo.
[14] Mahadeva L. y Robinson P. (2009). Prueba de Raíz Unitaria para ayudar a la construcción de un Modelo, Ensayos, 76. México: Centro de Estudios Monetarios Latinoamericanos (CEMLA).

[15] Castaño E. y Martínez M. (2008). Uso de la función de correlación cruzada en la identificación de modelos ARIMA, Revista Colombiana de Estadística, 31 (22), Colombia.

[16] Blacona, M., Bussi, J. y Méndez, F. (2008). El ciclo del PIB y su relación con otras variables económicas en Argentina. Décimo tercera Jornada "Investigaciones en la Facultad", Facultad de Ciencias Económicas y Estadística, Universidad Nacional de Rosario. Argentina.

[17] Jeréz, M. (2014). Regresión con series temporales. Notas del curso, Universidad Complutense de Madrid, Facultad de Ciencias Económicas. Departamento de Economía Cuantitativa.

[18] Cejudo, G. y Michel, C. (2016). Coherencia y políticas públicas: Metas, instrumentos y poblaciones objetivo. Gestión y Política Pública, Centro de Investigaciones y Docencias Económicas (CIDE), XXV (1), pp. 3-31.

[19] Centro de Investigación Económica y Presupuestaria, CIEP (2016). Introducción al Sistema Fiscal Mexicano. Ciclo de conferencias Finanzas Públicas: Las reformas estructurales. México: Auditoría Superior de la Federación, pp. 3-5.

[20] Constitución Política de los Estados Unidos Mexicanos.

[21] De la Garza, S. (2012). Derecho financiero mexicano. México: Porrúa.

[22] Mabarak, D. (2000). Derecho financiero público. México: McGraw-Hill, p. 22.

[23] Hernández, J. (2009). La composición del gasto público y el crecimiento económico. Análisis Económico, XXIV (55); pp. 77-102. Universidad Autónoma Metropolitana Unidad Azcapotzalco.

[24] Jiménez, F. (2005). Regla de oro, sostenibilidad y regla fiscal contracíclica. XVII Seminario Regional de Política Fiscal CEPAL /ECLAC, Naciones Unidas. Santiago de chile, 24-27 enero de 2005.

[25] Fonseca, F. (2009). El impacto de la inversión pública sobre la inversión privada en México 1980-2007. Estudios Económicos, 24 (2); El Colegio de México, pp. 187-224.

[26] Hernández, J. (2010). Inversión pública y crecimiento económico: Hacia una nueva perspectiva de la función del gobierno. Economía: teoría y práctica, 33; pp. 1-19.

[27] Armendáriz, E., Contreras, E., Orozco, S. y Parra, G. (2016). La eficiencia del gasto de inversión pública en América Latina. XXI Congreso Internacional del CLAD sobre la Reforma del Estado y de la Administración Pública, Santiago, Chile, pp. 1-2.

[28] Lewis, V. y Winkler, R. (2017). Government spending, entry, and the consumption crowding-in puzzle. International Economic Review, 58 (3), pp. 943-971. 